
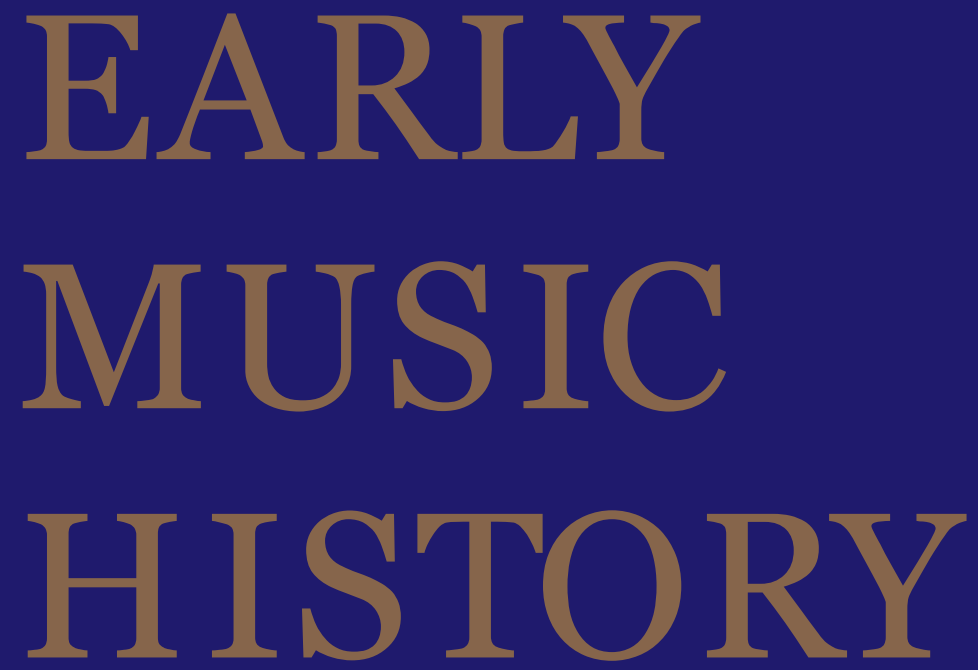

\title{
Studies in medieval and early modern music
}

Edited by Iain Fenlon 


\title{
EARLY MUSIC HISTORY 33
}

\section{STUDIES IN MEDIEVAL \\ AND \\ EARLY MODERN MUSIC}

\author{
Edited by \\ IAIN FENLON \\ Fellow of King's College, Cambridge
}


Published by the Press Syndicate of the University of Cambridge The Edinburgh Building, Cambridge CB2 8RU, United Kingdom 32 Avenue of the Americas, New York, NY 10013-2473, USA

47 Williamstown Road, Port Melbourne, VIC 3207, Australia C/Orense, 4, Planta 13, 28020 Madrid, Spain

Lower Ground Floor, Nautica Building, The Water Club, Beach Road, Granger Bay, 8005 Cape Town, South Africa

(C) Cambridge University Press 2014

First Published 2014

\author{
Phototypset in Baskerville in the United Kingdom by \\ Henry Ling Limited, at the Dorset Press, Dorchester, DT1 1HD \\ Printed in the United Kingdom by Bell \& Bain Ltd
}

ISSN 0261-1279

SUBSGRIPTIONS The subscription price (excluding VAT) of volume 33, which includes postage plus electronic access to institutional subscribers only, is $\mathcal{E}_{155}$ (US $\$ 262$ in USA and Canada) for institutions, $£ 48$ (US $\$ 80$ in USA and Canada) for individuals (print only) ordering direct from the Press and certifying that the annual is for their personal use. An electronic only price is available to institutional subscribers for $\AA_{130}$ (US $\$ 219$ in USA and Canada). The print only price for institutions is $\mathcal{E} 150$ (US $\$ 244$ in USA and Canada). Copies of the annual for subscribers in the USA and Canada are sent by air to New York to arrive with minimum delay. Orders, which must be accompanied by payment, may be sent to a book-seller, subscription agent or direct to the publishers: Cambridge University Press, The Edinburgh Building, Shaftesbury Road, Cambridge CB2 8RU. Payment may be made by any of the following methods: cheque (payable to Cambridge University Press), UK postal order, bank draft, Post Office Giro (account no. 5716055 GB Bootle - advise CUP of payment), international money order, UNESCO coupons, or any credit card bearing the Interbank symbol. EU subscribers (outside the UK) who are not registered for VAT should add VAT at their country's rate. VAT registered subscribers should provide their VAT registration number. Japanese prices for institutions (including ASP delivery) are available from Kinokuniya Company Ltd, P.O. Box 55, Chitose, Tokyo. Orders from the USA and Canada should be sent to Cambridge University Press, Journals Fulfillment Department, 100 Brook Hill Drive, West Nyack, New York 10994-2133, USA.

INTERNET AGGESS This journal is included in the Cambridge Journals Online service which can be found at www.journals.cambridge.org/emh. For further information on other Press titles access www.journals.cambridge.org

This journal issue has been printed on FSC-certified paper and cover board. FSC is an independent, non-governmental, non-for-profit organization established to promote the responsibility management of the world's forests. Please see www.fsc.org for information. 


\section{GONTENTS}

Page

Mary Ghannen Caldwell (Wichita State University)

'Flower of the lily': Late-medieval religious and heraldic symbolism in Paris, Bibliothèque nationale de France, MS français 146

Ross W. Duffin (Case Western Reserve University)

Voices and viols, Bibles and bindings: The origins of the Blossom partbooks

ERIC JAs (Utrecht University)

What other Josquin?

EDward Nowacki (College-Conservatory of Music, University of Cincinnati)

The anonymous Musica in Leipzig, Universitätsbibliothek, MS 1492: A new edition and translation

Murray STEIB (Ball State University)

Herculean Labours: Johannes Martini and the manuscript Modena, Biblioteca Estense, MS a.M.1.13

\section{REVIEWS}

James Grier (ed.), Ademari Cabannensis opera liturgica et poetica: Musica cum textibus

SAM BARRETT

Emma Dillon, The Sense of Sound: Musical Meaning in France, $1260-1330$

JEREMY LLEWELLYN 


\section{EMERITUS BOARD}

F. Aberto Gallo, Dipartimento di Beni Culturali

James HaAr, University of North Carolina at Chapel Hill

Lewis Lockwood, Harvard University

Edward Roesner, New York University

AndRew Wathey, Northumbria University

\section{EDITORIAL BOARD}

Wulf ARlt, University of Basel

SAM BARRETt, University of Cambridge

Margaret Bent, All Souls College, Oxford

LoRenzo BiAnconi, University of Bologna

Bonnie J. Blackburn, Wolfson College, Oxford

JuAn-José Garreras, University of Zaragoza

Flora Dennis, University of Sussex

David Fallows, University of Manchester

Laurenz LütTeken, University of Zurich

Patrick Macey, Eastman School of Music

Anthony Newcomb, University of California at Berkeley

Susan Rankin, Cambridge University

ReInhard Strohm, University of Oxford

Kate van Orden, Harvard University

Philippe Vendrix, CESR, Tours, France 